\title{
Vaginal Probiotic Administration in The Management of Preterm Premature Rupture of Membranes
}

\author{
Farag A. Ibrahim , Mohammed K. Mostafa, Mohammed M. Farahat
}

Obstetrics and Gynecology Department, Faculty of Medicine, Al-Azhar University, Cairo, Egypt

\begin{abstract}
Background: Preterm premature rupture of membranes (PROM), refers to rupture of membranes before the onset of labour in women with a pregnancy $<37$ weeks gestation. It complicates $1-3 \%$ of all pregnancies and is responsible for approximately $30 \%$ of preterm deliveries.

Objective: This study aimed at examining the efficacy of a vaginal probiotic formula in combination with standard antibiotic prophylaxis on perinatal outcome in cases of PPROM before 34 weeks of gestation and comparing them with those treated only with antibiotics.

Methods: This is a prospective randomized controlled study conducted at the department of obstetrics \& gynecology and its out-patient clinic, El- Hussein University Hospital from august 1 st 2017 to august 1 st 2018 .

Results: During the study period, 73 pregnant women diagnosed as PPROM were invited to participate. Two of them denied, while the remaining 71 women accepted participation in our study ( 2 women of the study group were excluded due to poor compliance to the study protocol and 1 of each group was also excluded due to delivery in the first $48 \mathrm{~h}$ after the study entry). In total 67 women were included in the study. In our study the cases diagnosed as PPROM were divided into 2 groups: Group 1 ( study group ) consisted of 33 cases and group 2 (control group) consisted of 34 cases. There was no statistical significant difference between the two groups as regard mean gestational age at admission, age, height, weight ,parity and gravidy ( $\mathrm{p}$ value > 0.05). There was statistical significant difference between the two groups as regard history of PROM with higher cases in control group, gestational age at delivery (weeks) with higher percentage in study group and latency period with highly period in study group ( $\mathrm{p}$ - value $<0.05$ ). Also, in the present study as regard neonatal outcome there were significant statistical differences between the two groups as regard 1 and 5-minute APGAR score after birth with highest low score in control group .

Conclusion: This study demonstrated that the efficacy of a vaginal probiotic formula in combination with standard antibiotic prophylaxis on perinatal outcome in cases of PPROM before 34 weeks of gestation as compared to those treated only with antibiotics.
\end{abstract}

Keywords: Preterm premature rupture of membrane (PPROM) , Probiotics , Bacterial vaginosis.

\section{INTRODUCTION}

Preterm premature rupture of membranes PROM, refers to rupture of membranes before the onset of labour in women with a pregnancy <37 weeks gestation. It complicates $1-3 \%$ of all pregnancies and is responsible for approximately $30 \%$ of preterm deliveries ${ }^{(\mathbf{1}}$.

It may result in devastating maternal, fetal, and neonatal outcome. The risk of severe perinatal complications such as, chorioamnionitis, cord compression, abruptio placenta, neonatal sepsis, respiratory distress syndrome, intraventricular bleeding, and even neonatal death is also increased following PPROM ${ }^{(2)}$.

The etiology of this complication is not completely understood. However, infections seem to play a major role, as in $36 \%$ of cases, there are positive amniotic fluid cultures (3). Moreover , bacteria that are normally found in the vagina may enter the amniotic cavity following amniorrhexis and can cause ascending infection.

Among women with PPROM who were managed expectantly, there were a significantly increased number of cases with chorioamnionitis, in comparison with those who had labor induction ${ }^{(4)}$.

The standard care of PPROM cases before 34 weeks involves the administration of glucocorticoids and antibiotics ${ }^{(5)}$.

Antibiotic treatment reduces the rate of chorioamnionitis and improve the perinatal oucome by prolonging the latency period ${ }^{(6)}$.

Probiotics are live microorganisms that exert various beneficial effects on human health ${ }^{(7)}$. Several reports in the literature indicated that they could protect against genital infections and restore the normal vaginal flora in women ${ }^{(8)}$.

The actual mechanism of action of Probiotics in the vagina is probably multifactorial.

The production of lactic acid, bacteriocin, and hydrogen peroxide seems to be important, and modulation of immunity is another possible mechanism ${ }^{(9)}$.

The administration of these lactobacilli by mouth or intravaginally, or both, has been shown to be safe and effective in reducing, or treating, urogenital infections (10). 


\section{PATIENT AND METHODS}

\section{- Study Type:}

A Prospective randomized controlled study .

\section{- Study settings:}

The study was performed on cases presented to the Out-patient Clinic of the department of Obstetrics \& Gynecology, El- Hussein University Hospital from august 1 st 2017 to august 1 st 2018. The institutional review board approved the study protocol and an informed consent was obtained from all participants prior to commencement of the study. - In our study the cases which diagnosed as PPROM were divided into 2 groups :

Group 1 (( study group )): received 3 doses daily of 1 g. of amoxicillin and 2 doses of $500 \mathrm{mg}$ of metronidazole intravenously daily for 2 days, then orally for another period of 8 days. In addition, this group received vaginal probiotic capsules for the same 10 day period.

Group 2 (( controls )): received the same antibiotic treatment for the same period without probiotic administration

* 2 doses of betamethazone $12 \mathrm{mg}$ were also given to all patients $24 \mathrm{~h}$ apart.

* Tocolytics were not given in any case.

\section{The follow up included:}

* Daily clinical examination and vital signs check at 4- hours intervals.

* Fetal heart rate auscultation was recorded every $8 \mathrm{~h}$.

* C - reactive protein levels (CRP) and white blood cell count (WBCs) were calculated twice a week.

* Ultrasonographic evaluation: was also performed twice a week, unless differently indicated.

* Genital and urinary tract cultures were taken every 10 days.

Delivery was planned at 36 weeks by either induction of labor or Caesarean section if there was an indication for it.

Delivery indication included chorioamnionitis, signs of fetal distress or abnormal fetal Doppler, and regular uterine contractions with advanced cervical dilatation $\geq 4 \mathrm{~cm}$. Chorioamnionitis was suspected when maternal heart rate is $>100$ beats per minute or fetal tachycardia (persistent baseline fetal heart rate
$>160$ beats per minute), maternal pyrexia $\left(\geq 37.5^{\circ} \mathrm{C}\right.$ on two occasions $2 \mathrm{~h}$ apart, or $>38{ }^{\circ} \mathrm{c}$ once ), leucocytosis (WBC count $>15000 / \mathrm{mm}^{3}$ ), uterine tenderness, or offensive vaginal discharge.

The primary outcome was gestational age at birth, duration of the latency period and birth weight .

The secondary outcomes were the neonatal deaths.

\section{Inclusion criteria :}

All women with PPROM between 24 and 34 weeks of gestation were invited to participate in this study. PPROM was diagnosed by the history, speculum examination and the observation of amniotic fluid collection, as well as by a positive nitrazine test. In all cases, the diagnosis was supported by a reduced amount of amniotic fluid ( largest pocket of amniotic fluid was < 2) found in the admission ultrasonographic scan.

In cases of clinical doubt, where a history of loss of amniotic fluid was reported with a negative nitrazine test and negative findings on clinical examination, women were observed for $24 \mathrm{~h}$ and if the nitrazine test was negative and amniotic fluid remained normal, they were not considered eligible for the study.

\section{Exclusion criteria:}

The presence of active labor, vaginal bleeding, signs of infection, medical or obstetric complications such as hypertensive disorders, diabetes mellitus, growth restriction, fetal distress, multiple pregnancy or fetal congenital defects. Women who gave birth during the first $48 \mathrm{~h}$ after their hospital admission were also excluded..

Gestational age was determined by the last menstrual period or by the first-or second- trimester ultrasound scan if there was a discrepancy of more than a week.

\section{Statistical Analysis and Results}

Statistical analysis was done using IBM $\odot$ SPSS $\odot$ Statistics version 21 (IBM $\odot$ Corp., Armonk, NY, USA) and MedCalc@() version 12.5 (MedCalc@ Software bvba, Ostend, Belgium). Continuous numerical data were presented as mean and SD and inter-group differences were compared using the unpaired Student $t$ test.

A two-sided p-value $<0.05$ was considered statistically significant and $<0.001$ was considered highly statistically significant. 


\section{RESULTS}

In our study the cases which diagnosed as PPROM were divided into 2 groups: Group 1 ( study group ) consisted of 33 cases and group 2 (control group) consisted of 34 cases as shown in figure (1) .

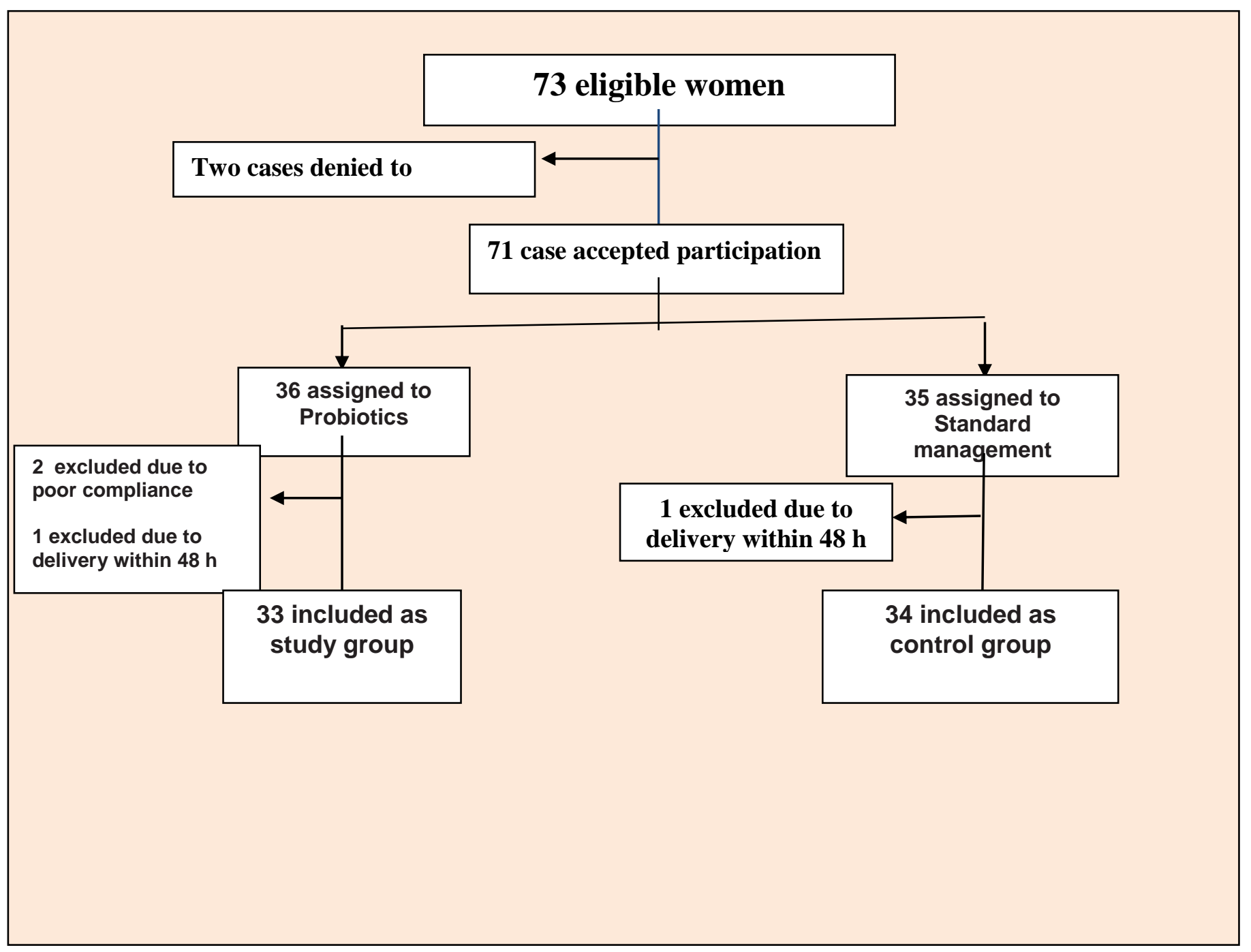

Figure (1): Patient' flow diagram

Table (1): Classification of the study cases according to the main gestational age on admission

\begin{tabular}{|c|c|c|c|}
\hline Variant & $\begin{array}{c}\text { Study group } \\
(\mathbf{n}=\mathbf{3 3})\end{array}$ & $\begin{array}{c}\text { Control group } \\
(\mathbf{n}=\mathbf{3 4})\end{array}$ & P value \\
\hline $\begin{array}{c}\text { Main Gestational age on } \\
\text { admission (weeks) }\end{array}$ & $29.2 \pm 0.5$ & $30.7 \pm 0.5$ & $0.45(\mathrm{NS})$ \\
\hline $\begin{array}{l}\text { Data is presented as mean } \pm \text { standard deviation or frequency (percentage). A two-sided P value of } \\
\text { less than 0.05 was considered statistically significant. }\end{array}$ \\
\hline
\end{tabular}

This table showed that 71 PROM cases had completed the study that are classified to 33 cases as a study group with mean gestational age at admission $29.2 \pm 0.5$ weeks and 34 cases as a control group with mean gestational age at admission $30.7 \pm 0.5$ weeks. There was no statistical significant difference between the two groups. 


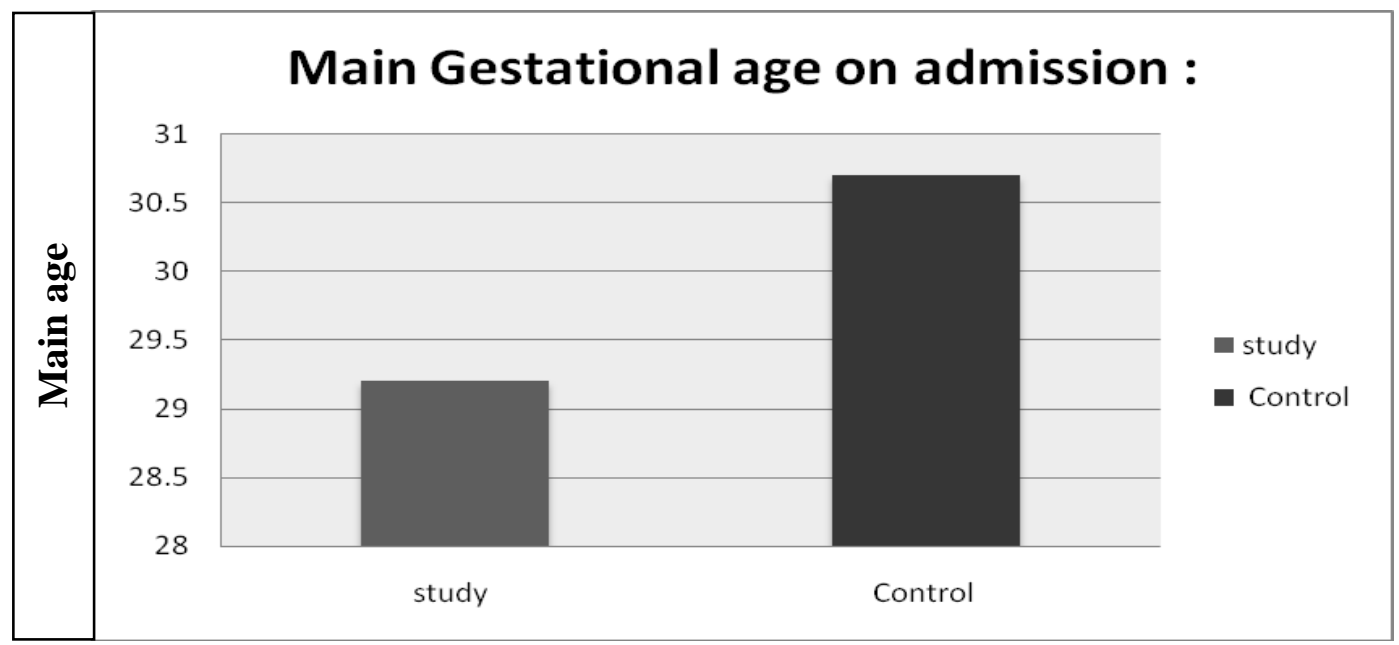

Figure (2): The main gestational age on admission.

Table (2): Patients characteristics

\begin{tabular}{|l|c|c|c|c|c|}
\hline & \multicolumn{2}{|c|}{ Study group } & \multicolumn{2}{c|}{ Control group } & \\
\hline Variable & Mean & SD & Mean & SD & p-value \\
\hline Age (years) & 24.8 & 4.9 & 27.8 & 6.3 & 0.495 \\
\hline Weight (kg) & 67.2 & 13.4 & 75.0 & 10.2 & 0.16 \\
\hline Height (cm) & 161.5 & 6.5 & 160.3 & 7.2 & 0.519 \\
\hline Parity & 1.5 & 0.23 & $\square \square \square \square$ & 0.26 & 0.243 \\
\hline Gravidy & 2.9 & 0.012 & 2.7 & 0.011 & 0.213 \\
\hline
\end{tabular}

There was no statistical significant (NS) difference between the two groups as regard age, height, weight, parity and gravidy ( $\mathrm{p}$ value $>0.05$ ).

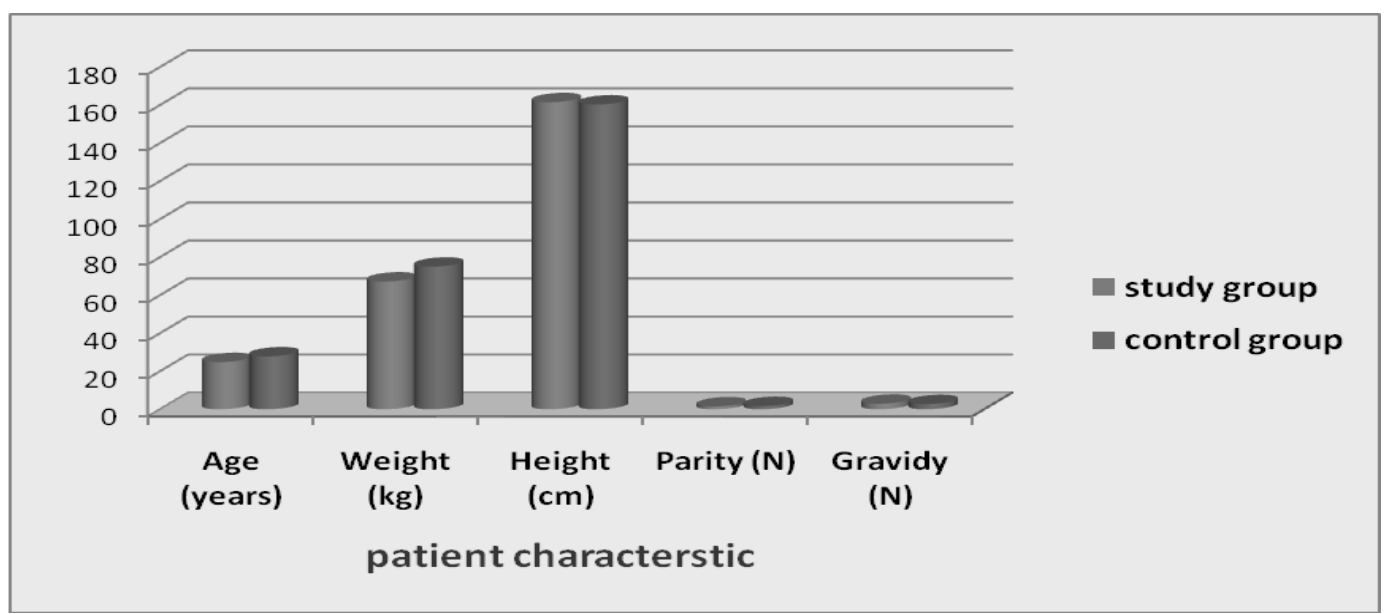

Figure (3): Patients characteristics.

Table (3): Distribution of cases as regard history of PPROM

\begin{tabular}{|c|c|c|c|}
\hline \multicolumn{1}{|c|}{ Variable } & $\begin{array}{c}\text { Study group } \\
(\mathbf{n = 3 3})\end{array}$ & $\begin{array}{c}\text { Control group } \\
(\mathbf{n}=\mathbf{3 4})\end{array}$ & p-value \\
\hline History of PPROM & $\square$ & $\square$ & $<0.001^{*}$ \\
\hline
\end{tabular}

There was statistical significant difference between the two groups as regards history of PROM with higher cases in control group. 


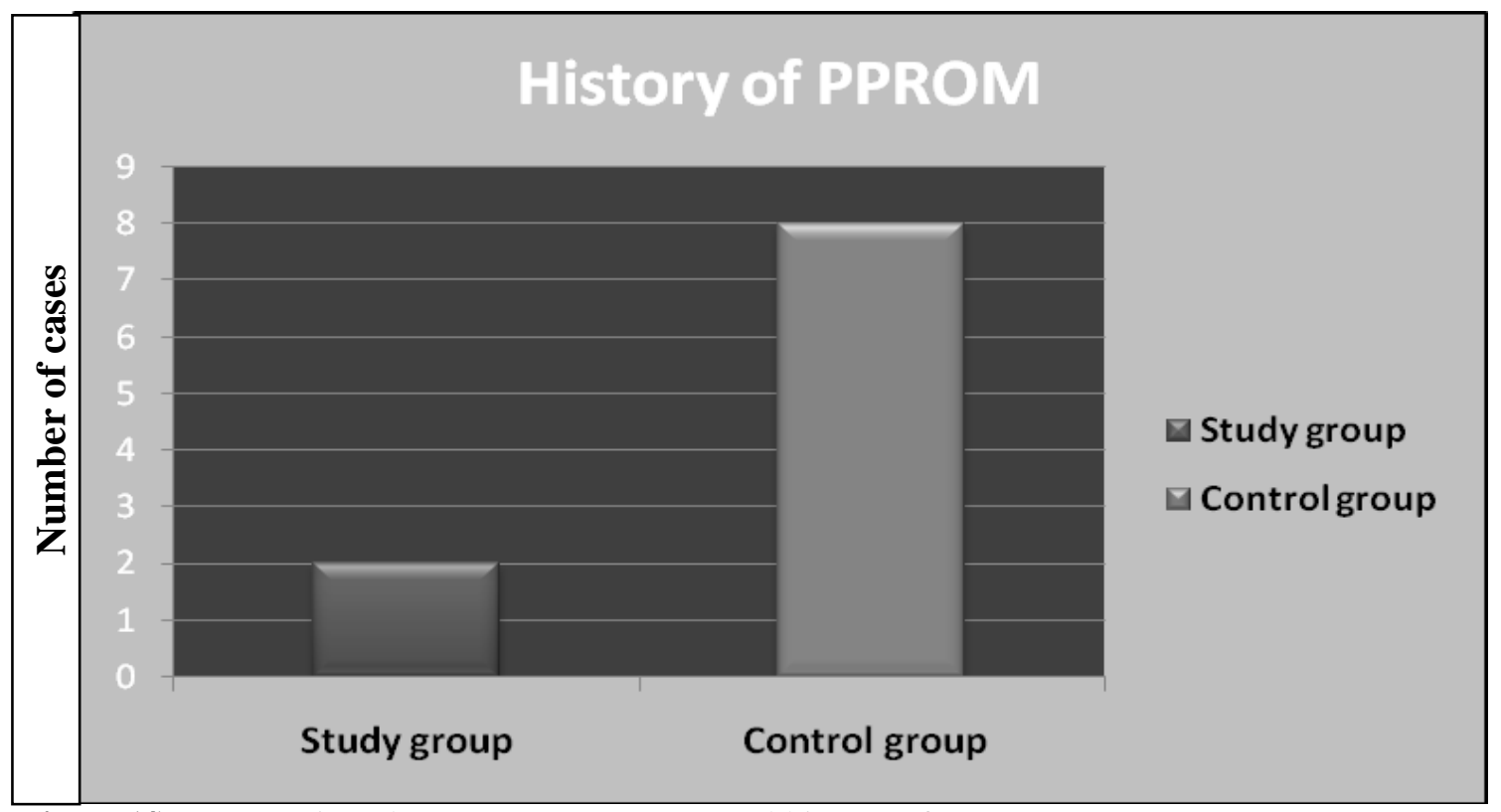

Figure(4): Comparison between groups as regard history of PROM

Table (4): Distribution of cases as regards gestational age at delivery

\begin{tabular}{|c|c|c|c|}
\hline Variable & $\begin{array}{c}\text { Study group } \\
(\mathbf{n = 3 3})\end{array}$ & $\begin{array}{c}\text { Control group } \\
(\mathbf{n}=\mathbf{3 4})\end{array}$ & p-value \\
\hline Gestational age at delivery (weeks) & $\square \square \square \square \square \square \square \square \square$ & $\square \square \square \square \square \square \square \square \square \square$ & $<0.001$ \\
\hline
\end{tabular}

There was statistical significant difference between the two groups as regards gestational age at delivery (weeks) with higher percentage in study group .

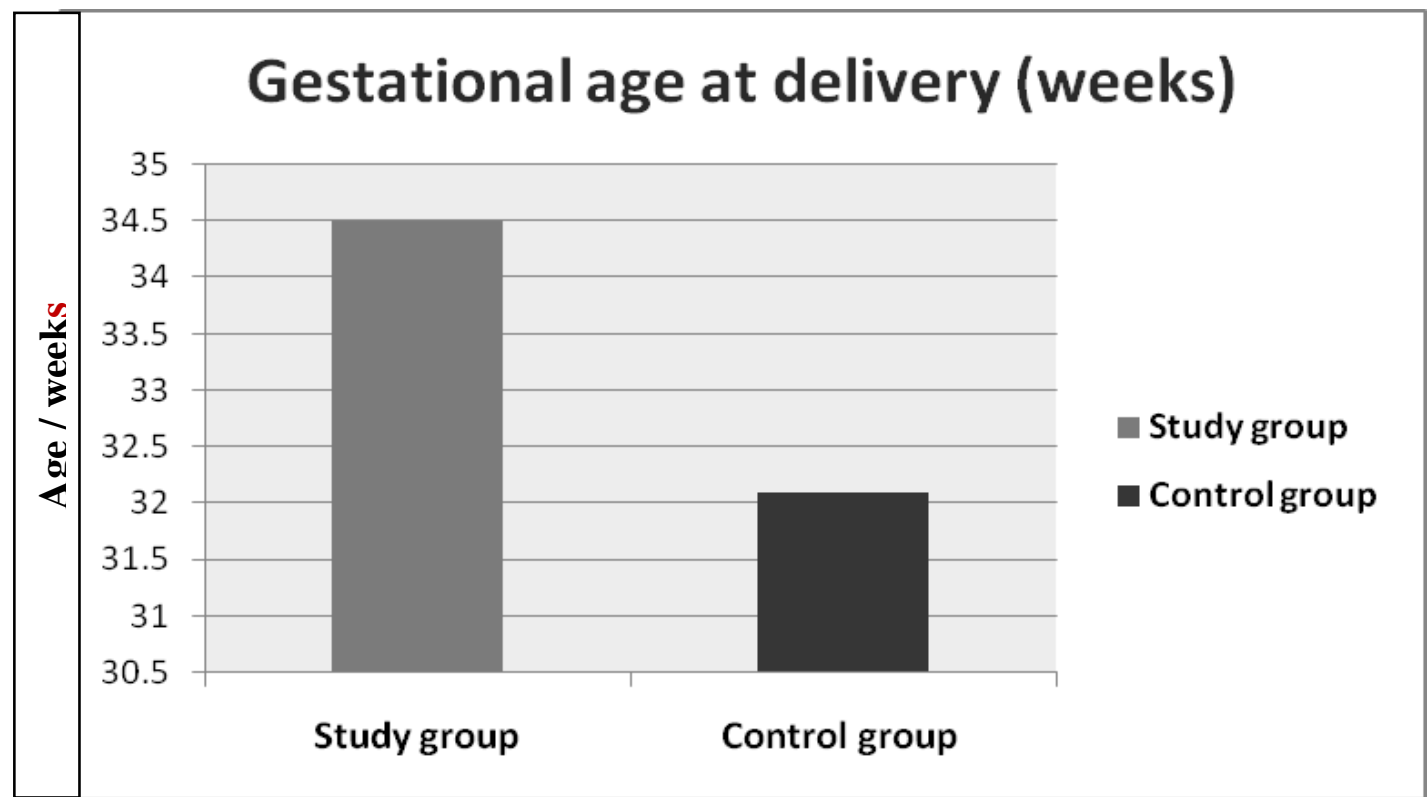

Figure (5): Gestational age at delivery.

Table (5): Comparison between study and control groups as regards latency period

\begin{tabular}{|l|c|c|c|}
\hline \multicolumn{1}{|c|}{ Variable } & $\begin{array}{c}\text { Study group } \\
(\mathbf{n = 3 3})\end{array}$ & $\begin{array}{c}\text { Control group } \\
(\mathbf{n}=\mathbf{3 4})\end{array}$ & p-value \\
\hline latency period (days) & $\square \square \square \square \square \square \square \square \square \square \square$ & $\square \square \square \square \square \square \square \square \square \square \square$ & $<0.001$ \\
\hline
\end{tabular}

There was statistically highly significant difference between the two groups regarding latency period with highly period in study group as $\mathrm{p}$ - value $<0.001$. 
Vaginal Probiotic Administration...

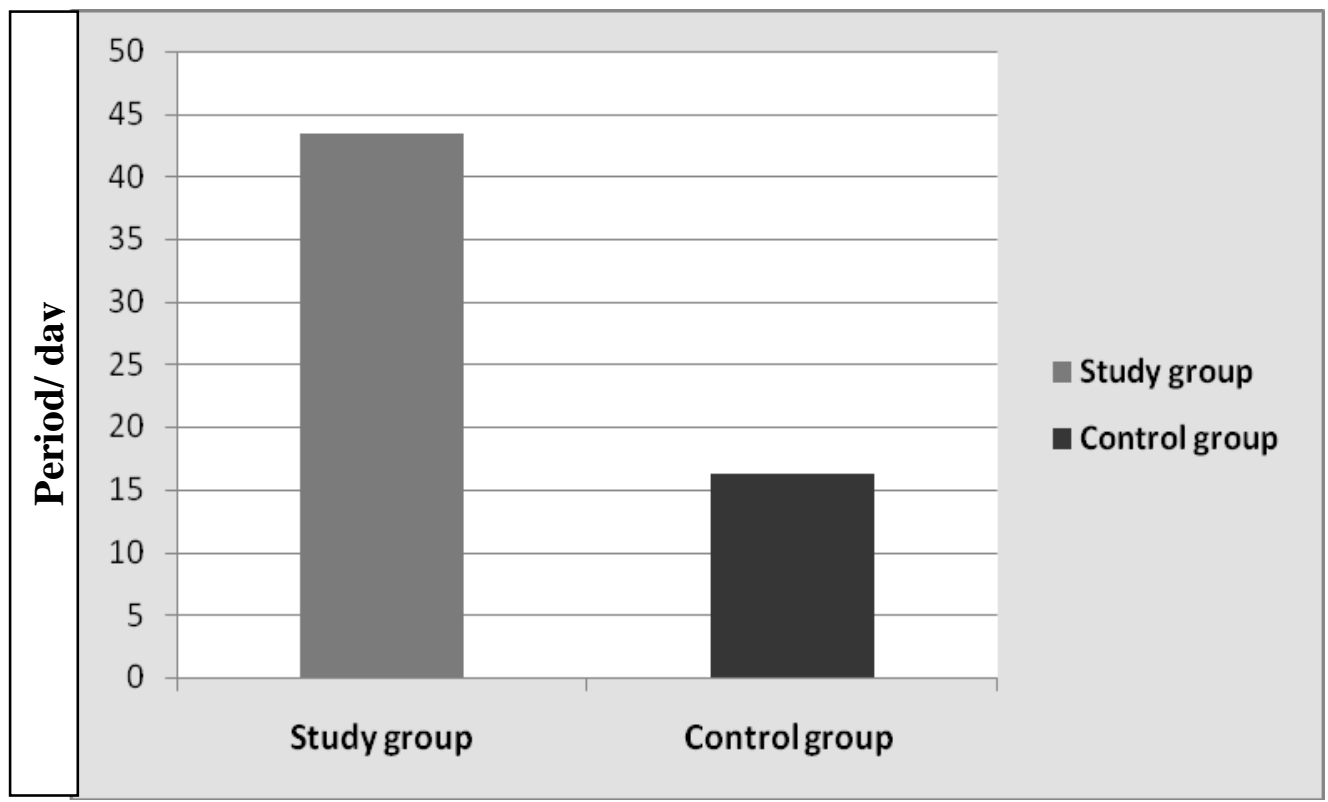

Figure (6): Distribution of cases as regard latency period .

Table ( 6) : Distribution of cases as regards type of delivery

\begin{tabular}{|c|c|c|c|c|c|}
\hline \multirow{2}{*}{ Variable } & \multicolumn{2}{|c|}{$\begin{array}{c}\text { Study group } \\
(n-32)\end{array}$} & \multicolumn{2}{|c|}{$\begin{array}{c}\text { Control group } \\
(\mathbf{n}-\mathbf{3 4})\end{array}$} & \multirow[t]{2}{*}{ p-value } \\
\hline & $\mathbf{N}$ & $\%$ & & & \\
\hline $\begin{array}{l}\text { Spontaneous delivery } \\
\text { (labour pain ) }\end{array}$ & $\square \square$ & $\square \square \square \square$ & $\square \square$ & 55.9 & 0.069 \\
\hline Cesarean section (CS) & $\square \square$ & पि口० & $\square \square$ & पिए६ & 0.001 \\
\hline
\end{tabular}

There was statistically significant difference between the two groups regarding spontaneous delivery and cesarean section (CS) with high incidence of CS in control group p value was $<0.001$.

Table (7): Comparison between study and control groups as regards neonatal birth weight

\begin{tabular}{|c|c|c|c|}
\hline \multicolumn{1}{|c|}{ Variable } & $\begin{array}{c}\text { Study group } \\
(\mathbf{n = 3 3})\end{array}$ & $\begin{array}{c}\text { Control group } \\
(\mathbf{n}=\mathbf{3 4})\end{array}$ & p-value \\
\hline Neonatal birth weight $(\mathrm{g})$ & $\square \square \square \square \square \square \square \square \square$ & $\square \square \square \square \square \square \square \square \square \square$ & 0.032 \\
\hline
\end{tabular}

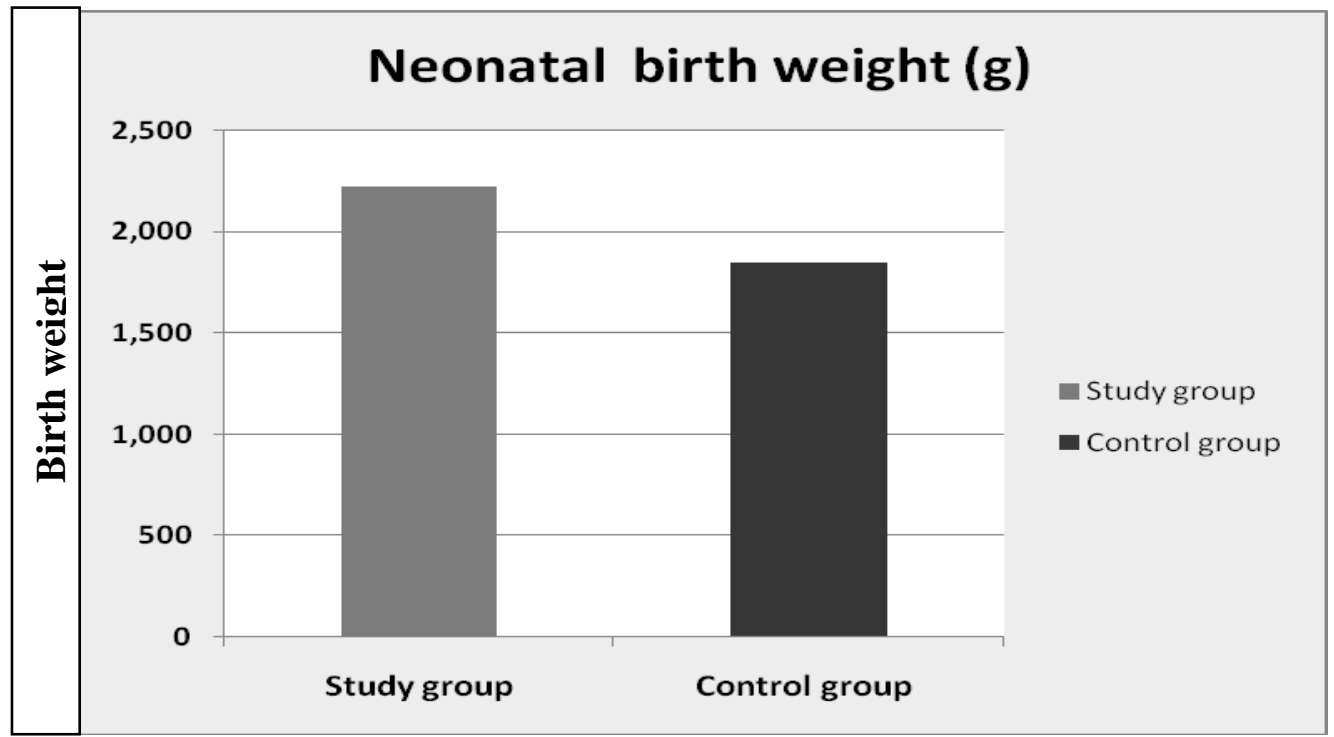

Figure (7): Comparison between study and control groups as regards neonatal birth weight

There was statistical significant difference between the two groups as regard birth weight. It was higher in study group . 
Farag Ibrahim et al.

Table (8): Comparison between study and control groups as regards laboratory findings ( total leucocytic count)

\begin{tabular}{|c|c|c|c|}
\hline Variable & $\begin{array}{l}\text { Study group } \\
\quad(\mathbf{n}=33)\end{array}$ & $\begin{array}{c}\text { Control group } \\
\quad(\mathrm{n}=34)\end{array}$ & $\overline{\text { p-value }}$ \\
\hline WBC $\left(/ \mathrm{mm}^{3}\right)$ at admission & $\begin{array}{c}\square \square \square \square \square \square \square \square \square \\
\square \square \square \square\end{array}$ & 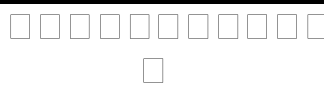 & 0.24 \\
\hline WBC $\left(/ \mathrm{mm}^{3}\right)$ at delivery & $\begin{array}{c}\square \square \square \square \square \square \square \square \square \\
\square \square \square \square\end{array}$ & 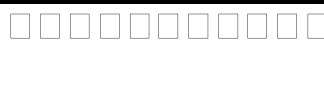 & $0.09 *$ \\
\hline
\end{tabular}

*significant

Abbreviation WBC (white blood cells )

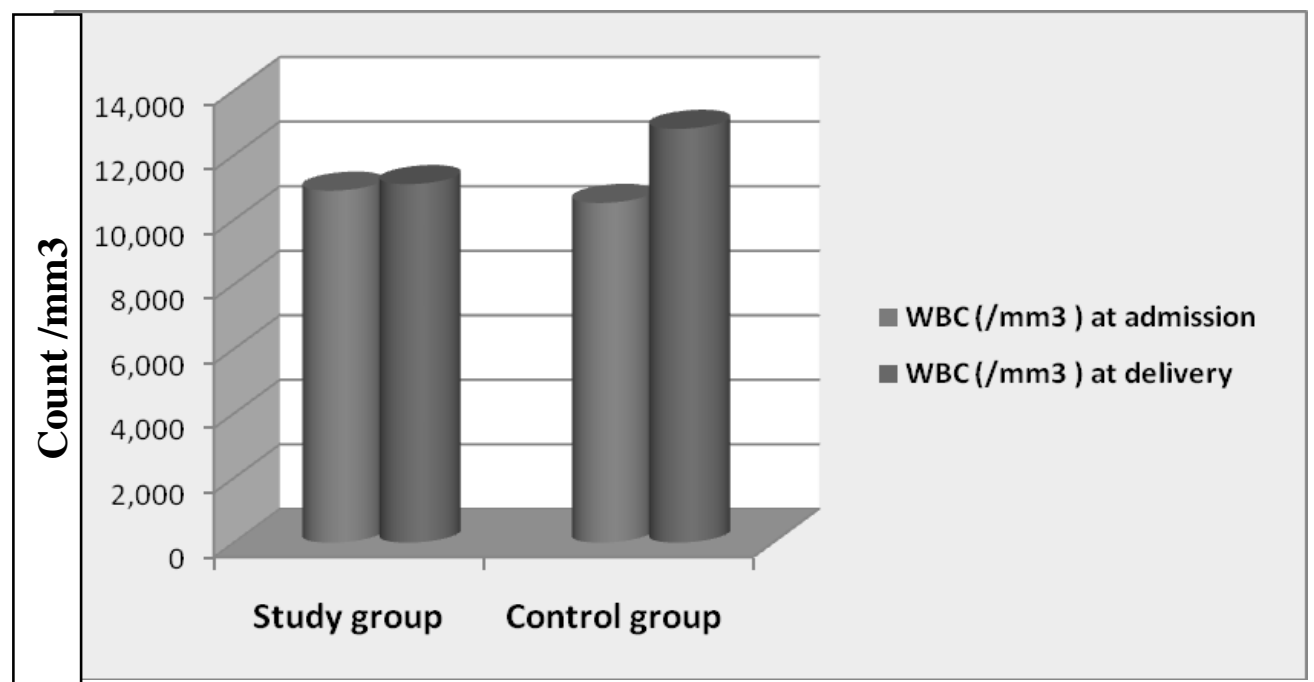

Figure (8): Comparison between study and control groups as regards laboratory findings ( total leucocytic count)

Table (9): Comparison between study and control groups as regard admission to neonatal intensive care

\begin{tabular}{|l|c|c|c|c|c|}
\hline \multicolumn{1}{|c|}{ Uariable } & \multicolumn{2}{|c|}{$\begin{array}{c}\text { Study group } \\
(\mathbf{n = 3 3})\end{array}$} & \multicolumn{2}{c|}{$\begin{array}{c}\text { Control group } \\
(\mathbf{n = 3 4})\end{array}$} & p-value \\
\hline & $\mathbf{N}$ & $\%$ & $\mathbf{N}$ & $\%$ & \\
\hline Admission to NICU & $\square$ & 24.3 & $\square \square$ & 55.8 & 0.003 \\
& $\square$ & & $\square$ & & \\
\hline
\end{tabular}

There was statistical significant difference between the two groups as regard NICU admission after delivery and it was higher in control group . 


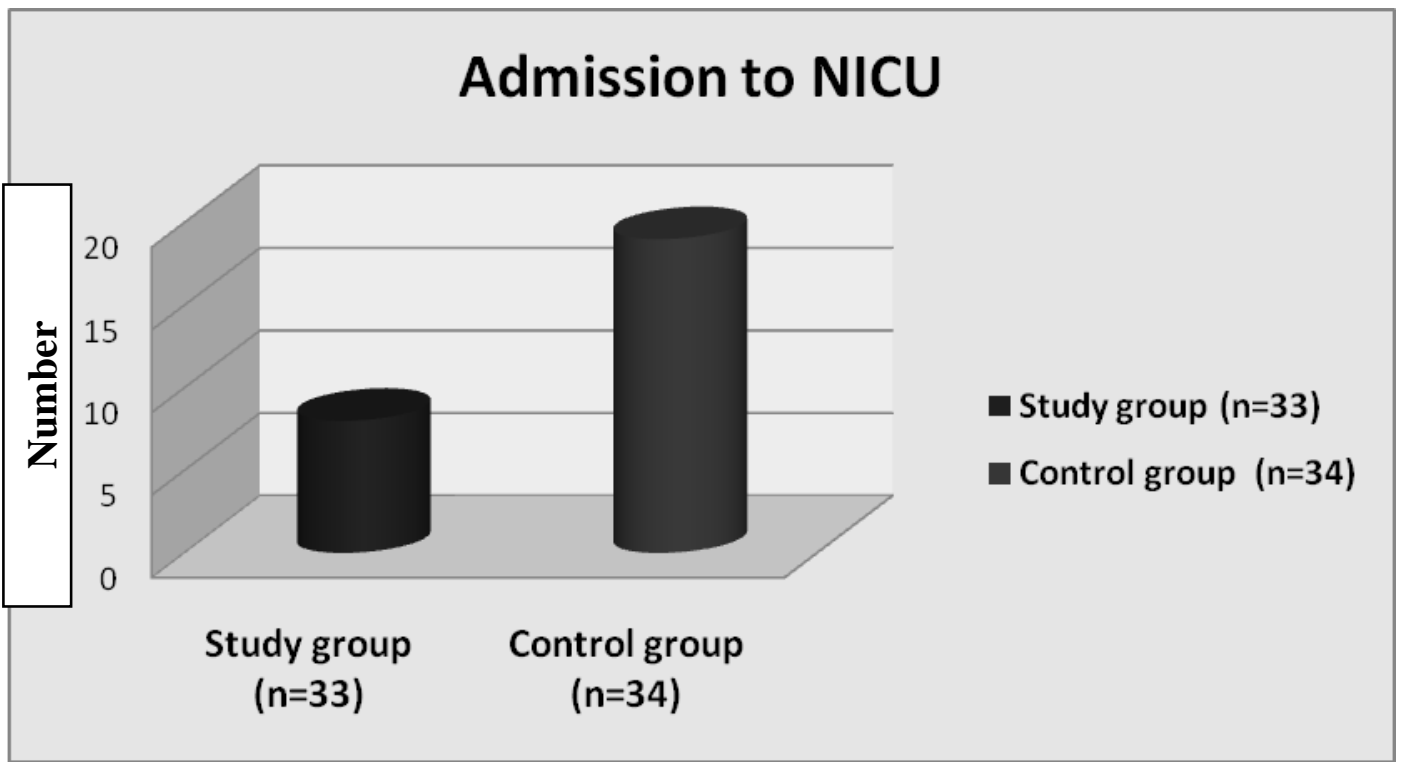

Figure (9): Comparison between study and control groups as regards NICU admission. Table (10): Comparison between groups regarding length of stay in neonatal special care unit(days)

\begin{tabular}{|l|c|c|c|}
\hline \multicolumn{1}{|c|}{ Variable } & $\begin{array}{c}\text { Study group } \\
(\mathbf{n = 3 3})\end{array}$ & $\begin{array}{c}\text { Control group } \\
(\mathbf{n = 3 4})\end{array}$ & p-value \\
\hline $\begin{array}{l}\text { length of stay in NICU } \\
\text { (days) }\end{array}$ & $9(6-17)$ & $\square \square \square \square \square \square \square \square \square$ & $\mathbf{0 . 0 5}$ \\
\hline
\end{tabular}

There was statistical significant difference between the two groups as regards length of stay in neonatal special care unit (days) after delivery and it was higher in control group .

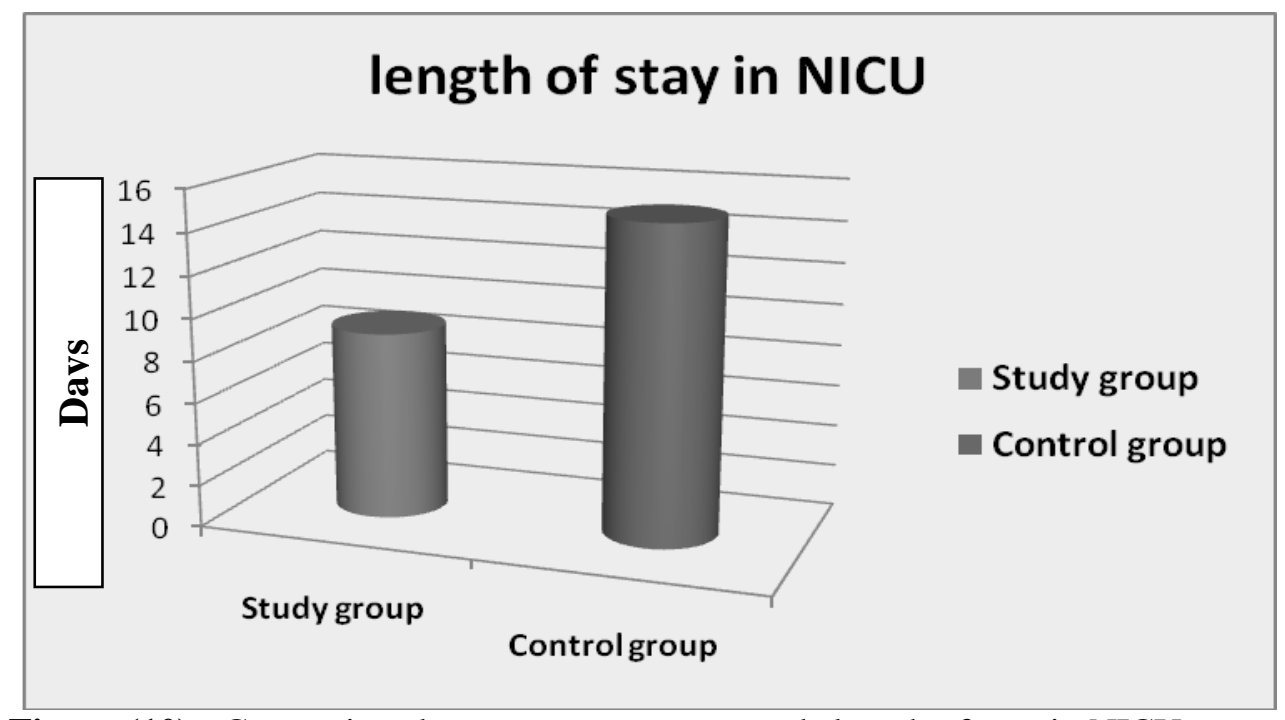

Figure (10) : Comparison between groups as regards length of stay in NICU

\section{DISCUSSION}

Bacterial vaginosis (BV) is the primary cause of abnormal vaginal discharge. In epidemiologic studies of women with vaginitis, at least 30 to $50 \%$ of all women have BV (11). In 1993 a study carried out in Egypt by Younis and his colleagues showed that the prevalence of BV was 22\% among Egyptian women in rural areas ${ }^{(12)}$. However, in 2005 another study showed a higher prevalence $(55.5 \%)$ of BV among non pregnant females attending the outpatient clinics of Ain Shams University Maternity Hospital ${ }^{(\mathbf{1 3})}$.

In obstetrics, bacterial vaginosis and its related organisms have been implicated in higher rates of late miscarriage, preterm premature rupture of membranes (PROM), chorioamnionitis, spontaneous preterm labour (SPTL), Preterm birth, and postpartum 
endomelritis (14). Pharmaceutical interventions, such as antibiotics are suboptimally effective. The absence of lactobacilli in the vagina, a specific feature of BV, raises the question of whether restoration of lactobacilli, by probiotic therapy, can restore the normal flora, improve the cure rate and prevent recurrence of $\mathrm{BV}$. The rationale for probiotic use in managing $\mathrm{BV}$ women is quite strong, where certain lactobacilli strains can safely colonize the vagina after oral and vaginal administration, displace and kill pathogens including G. vaginalis and E. coli, and modulate the immune response to interfere with the inflammatory cascade that leads to preterm birth ${ }^{(\mathbf{1 0})}$.

In the present study, there was statistical significant difference between the two groups as regards gestational age at delivery and latency period with significant increase in study group than control. The latency time between PPROM and delivery seems to be a key point to improve perinatal morbidity and mortality. Increase of this period could help attending physicians in PPROM management ${ }^{(\mathbf{1})}$.

In agreement with our study, Giuseppe Luzi et al. study showed a statistical significant increase ( $\mathrm{p}=$ 0.04) of delivery gestational age when compared with the women treated only with standard therapy. The time course between PPROM and delivery was $26.5 \pm$ 27.4 days in the lactobacillus-treated group and 11.6 \pm 14.2 days in the other group $\left(\mathrm{p}=0.03^{(\mathbf{1 5})}\right.$.

The latent period is the length of time required since the rupture of the membranes to the onset of labor. The longer the latent period, the greater the risk of infection in the mother and fetus ${ }^{(16)}$.

The latency period is significantly longer in PPROM cases managed actively with prophylactic antibiotics (17). For that purpose, one of the most preferred regimes is that recommended by the National Institute of Child Health and Human Development (NICHD) where intravenous (IV) ampicillin is started in the first 48 hours, and maintenance treatment with amoxicillin or enteric coated erythromycin is given in the following 5 days. Our study is in agreement with Kavak SB et al. study at which the latency period was $12.3 \pm 1.5$ days in group 1 (treated with ampicillin only) and $41.4 \pm 4.4$ days in group 2 ( treated with ampicillin plus probiotics) ${ }^{(18)}$. Lieman reported that the longest latency durations were between 28 and 31 weeks with shorter latency before and after these gestational ages ${ }^{(19)}$.

In the present study, there was statistically highly significant difference between the two groups regarding spontaneous delivery and cesarean section (CS) with low incidence of CS among study group (27.2\%) and high incidence of CS among control group $(44.1 \%)$. Our study is concomitant with a study included (536) cases in Iran, which showed that cesarean section in cases with PROM was $28.08 \%$.

Chakraborty et al. reported a cesarean section rate of $26.6 \%$ among pregnancies with prelabour rupture of membranes in a study conducted in West Bengal ${ }^{(20)}$.
Kunze et al. conducted a study with 1026 cases with PROM. In their study they reported a cesarean section rate of $(27 \%)^{(\mathbf{2 1})}$.

In the present study there was significant statistical difference between the two groups as regards 1-minute and 5-minute APGAR score after birth with high score in study group than control group. PROM is one of the most common complications in pregnancy that can affect the value of the infant APGAR (22). In accordance with our study, Salany reported in his study, at which there were 89 cases that met the inclusion criteria, that 57 cases were PROM $\leq 12$ hours. Of the total case group, PROM $\geq 12$ hours, 16 cases got good APGAR and 16 cases got bad APGAR (23). This was comparable to the studies conducted by Onyearugha et $\boldsymbol{a l}$. (24) and Dongol et al. ${ }^{(25)}$ which showed that at 1 minute most of the newborns had an Apgar score of 3 (62.7\%) and at 5 minutes most of the cases had a score of $6(25.3 \%)$ followed by $7(20 \%)$ and then $5(18.7 \%)$. In addition, Padayachee $\boldsymbol{e t}$ al. ${ }^{(26)}$ reported that most of the scores at 1 minute, 5 minutes and 10 minutes were 3,4 and 6 respectively. At 10 minutes most of our cases in this study, had an Apgar score of 8 (29.3\%) followed by $9(24 \%)$, then $7(14.7 \%)$. Another study showed that the mean scores at 1minute, 5 minutes, and 10 minutes was $2.53 \pm 0.664,5.37 \pm 1.505$ and $7.12 \pm 1.692$ respectively ${ }^{(26)}$. The mean Apgar score in a study by Casey et al. at 5 minutes was $6.6 \pm 2.1$ (27).

In the present study, there was statistical significant difference between the two groups as regard birth weight it was higher in study group (2,224 \pm 128). Furman et al. study showed that PROM was associated with lower gestational age and birth weight at delivery ${ }^{(28)}$.

This study is in agreement with Kavak et al. (29) study at which birth weights $(1,320 \pm 98 \mathrm{~g})$ in group 1 (treated with ampicillin only) and 1,947 \pm $128 \mathrm{~g}$ in group 2 ( treated with ampicillin plus probiotics), which was significantly higher in group 2. Moreover, this study coincides with study done by Kumar ${ }^{(30)}$, at which the incidence of birth weight inferior to the tenth percentile was significantly $(P<0.001)$ more frequent in the group reaching 37 weeks of gestation $(\mathrm{N}=9-$ $19.6 \%$ ) versus the group not reaching 37 weeks( $\mathrm{N}$ $=4-2.4 \%$ in). Previous studies have shown that PROM and preterm birth after PROM are associated with small-for-gestational age and low birth weight newborns. In addition, the high rate of cesarean sections, chorioamnionits, fetal distress and placental accidents were seen more frequently in these groups ${ }^{(31)}$.

In the present study, there was no statistical significant difference between the two groups as regards laboratory finding ( $\mathrm{WBCs})$ at time of admission but there was statistical significant difference between the two groups at time of delivery 
which was higher in control group than study group. Yoon et al. (32) published their study that was conducted on 90 women with PPROM where they showed that women with microbial invasion of the amniotic cavity ( MIAC) had higher maternal WBC counts at the time of admission to hospital. In present study, there was no statistical significant difference between the two groups as regards laboratory finding ( CRP) between both groups at time of admission and time of delivery.

Maternal serum CRP concentration is among the most commonly used clinical non-invasive markers to predict infectious-related and inflammatory complications in women with PPROM, in spite of the absence of strong evidence for its use in relation to these indications ${ }^{(33)}$. In agreement with our work a study conducted by Cobo et al. ${ }^{(34)}$ did not show any differences in maternal serum CRP concentration between women with and without MIAC. In the present study, there was statistical significant difference between the two groups as regards NICU admission after delivery and it was higher in control group. PROM accounts for $25-40 \%$ of all preterm deliveries that increase the risk of neonatal morbidity by $75 \%$. In addition, improvement in survival may be associated with adverse long term sequels needing more treatment and NICU hospitalization .In accordance with our study, Afrasiabi ${ }^{(35)}$ reported that there were 489 babies hospitalized in NICU for 1 to 54 days; $28.42 \%$ born were preterm, 308 with birth weight $<2500$ gram and 170 with birth weight between 2500 and 4000 gram. There was a significant relation between length of neonatal NICU stay and maternal PROM $(\mathrm{P}=0.001)$.

\section{CONCLUSION}

This study demonstrated the efficacy of a vaginal probiotic formula in combination with standard antibiotic prophylaxis on perinatal outcome in cases of PPROM before 34 weeks of gestation compared to those treated only with antibiotics.

\section{RECOMMENDATIONS}

1. We recommend the use of probiotics for treatment of bacterial vaginosis as it achieved higher cure rates and less recurrence than antibiotics regimen alone.

2. Probiotics are more natural with better compliance for patients with bacterial vaginosis than drug therapy, so it may be recommended to apply vaginal probiotics for patients with bacterial vaginosis to get better results.

3. Neonatal morbidity and mortality is lower in study group treated with probiotics than control group who were treated with antibiotics alone .

\section{REFERENCES}

1- Mercer BM (2003): Preterm premature rupture of the membranes. Obstetric Gynecology, 101: 178-193.
2- Kilbride HW, Thibeault DW (2001): Neonatal complications of preterm premature rupture of membranes: pathophysiology and management. Clinics in perinatology, 28 (4): 761-785.

4. Broekhuizen FF, Gilman MI, Hamilton PR (1985): Amniocentesis for gram stain and culture in preterm premature rupture of the membranes. Obstetrics and gynecology, 66 (3): 316321.

5. Naeff RW,Allbert JR, Ross EL, Weber BM, Martin RW, Morrison JC(1998): Premature rupture of membranes at 34 to 37 weeks' gestation: aggressive versus conservative management. Am J Obstet Gynecol., 178: 126130 .

6. ACOG Committee on Practice Bulletins-Obstetrics (2007):ACOG Practice Bulletin No 80: premature rupture of membranes. Clinical management guidelines for obstetrician-gynecologists. Obstet Gynecol., 109: 10071019.

6- Kenyon SL, Taylor DJ, Tarnow-Mordi W (2001): ORACLE Collaborative Group: Broad-

spectrum antibiotics for preterm, prelabour rupture of fetal membranes: the ORACLE I randomized

trial. ORACLE Collaborative Group. Lancet, 357: 979988.

7- Salminen S, Bouley C, Boutron-Ruault MC, Cummings JH, FranckA,Gibson GR, IsolauriE, Moreau MC, Roberfroid M, Rowland I (1998): Functional food science and gastrointestinal physiology and function. Br J Nutr., 80: S147-S171.

8- Vitali B, Cruciani F, Baldassarre ME, Capursi T, Spisni E, Valerii MC, Candela M, TurroniS, Brigidi $P$ (2012): Dietary supplementation with probiotics during late pregnancy: outcome on vaginal microbiota and cytokine secretion. BMC Microbiol., 12: 236.

9- Reid G, Burton J, Devillard E (2004): The rationale for Probiotics in female urogenital healthcare. Medscape General Medicine, 6 (1): 49.

10- Reid G, Bocking A (2003): The potential for probiotics to prevent bacterial vaginosis and preterm labor. American Journal of Obstetrics and Gynecology, 189 (4): 1202-8.

11- Shalev E, Battino $\mathbf{S}$,Weiner $\mathbf{E}$, Colodner $\mathbf{R}$, Keness Y (1996): Ingestion of yogurt containing Lactobacillus acidophilus compared with pasteurized yogurt as prophylaxis for recurrent candidal vaginitis and bacterial vaginosis. Archives of Family Medicine, 5(10): 593.

12-Younis N, Khattab H, Zurayk H , El-Mouelhy M, Amin MF, Farag AM. (1993). A community study of gynecological and related morbidities in rural Egypt. Studies in family planning, (1): 175-186.

13- El-Sokkary M (2011): Prevalence of asymptomatic bacteriuria in antenatal women with preterm labor at an Egyptian tertiary center. J Am Sci., 7 (4): 605-610.

14- Lamont RF, Oliver RS (2013): Infection and antibiotics in the aetiology, prediction and prevention of preterm birth. Journal of Obstetrics and Gynaecology, 33(8): 768-775.

15- Giuseppe Luzi et al. (2018): Lactobacillus Rhamnosus BMX 54 Vaginal application usefulness as adjuvant therapy for Preterm Premature Rupture of Membranes (PPROM) in the second Trimester of Pregnancy. Int J Ped \& Neo Heal, 2(1): 15-20.

16- Hackenhaar AA, Albernaz EP, FonsecaT (2014): 
Preterm premature rupture of the fetal membranes: association with sociodemographic factors and maternal genitourinary infections. Jornal de pediatria, 90 (2): 197202.

17- Queenan JT, Hobbins JC, Spong CY (2010): Preterm premature rupture of membranes. In: Mercer B. Protocols for High Risk Pregnancies. 5th ed. West Sussex: Wiley-Blackwell: 448-460.

18- Kavak SB, Kavak E, Ilhan R, Atilgan R,AratO,Deveci U, SapmazE (2014): The efficacy of ampicillin and Lactobacillus casei rhamnosus in the active management of preterm premature rupture of membranes remote from term. Drug Des Devel Ther., 8: 1169-1173.

19- Lieman JM, Brumfield CG, Carlo W, Ramsey PS (2005): Preterm premature rupture of membranes: Is there an optimal gestational age for delivery? Obstet Gynecol., 105: $12-17$.

20- Eslamian L, Asadi M (2002): The cesarean section rate in cases with PROM. Acta Medica Iranica, 40: 2.

21- Kunze M, Hart JE, Lynch AM, Gibbs RS (2011): Intrapartum management of premature rupture of membranes: effect on cesarean delivery rate. Obstetrics \& Gynecology, 118 (6): 1247-1254.

22- Nili F, Shams AA (2003): Neonatal complications of premature rupture of membranes. Acta Medica Iranica, 41 (3): 175-179.

23- Salany DC (2017): Effect of length of premature rupture of membranes period toward apgar score of the infant and maternal leukocyte serum in urine General Hospital Banjarmasin. Berkala Kedokteran Unlam., 13 (2): 199-204.

24- Onyearugha CN, Ugboma HA (2010): Severe birth asphyxia: Risk factors as seen in a tertiary institution in the Niger Delta area of Nigeria. Continental J Tropical Medicine, 4: 11-19.

25- Dongol S, Singh J, Shrestha S, Shakya A (2010): Clinical Profile of Birth Asphyxia in Dhulikhel Hospital: A Retrospective Study. J Nepal Paediatr. Soc., 30 (3): 141-6.

26- Padayachee N, Ballot DE (2013): Outcomes of neonates with perinatal asphyxia at a tertiary academic hospital in Johannesburg. S Afr J CH., 7 (3): 89-94.
27- Casey BM, Mcintire DD, Leveno KJ (2001): The continuing value of the Apgar score for the assessment of newborn infants. N Engl J Med.,344:467-71.

28- Furman B, Shoham-Vardi I, Bashiri A, Erez O and Mazor M. (2000): Clinical significance and outcome of preterm prelabor rupture of membranes: population-based study. Eur J Obstet Gynecol Reprod Biol., 92: 209 -216.

29- Kavak SB, Kavak E, Ilhan R, Atilgan R, Arat O, Deveci U, Sapmaz E (2014): The efficacy of ampicillin and Lactobacillus casei rhamnosus in the active management of preterm premature rupture of membranes remote from term. Drug Des Devel Ther., 8: 1169-1173. 30- Kumar S (2017): Outcome of neonates born to mothers with premature rupture of membranes. Journal, 3 (1): 66-70.

31- Pasquier JC, Rabilloud M, Picaud JC et al. (2005): A prospective population-based study of 598 cases of PROM between 24 and 34 weeks' gestation: description, management, and mortality. Eur J Obstet Gynecol Reprod Biol., 121 (2): 164-70.

32- Yoon BH, Jun JK, Park KH, Syn HC, Gomez R, Romero R (1996): Serum C-reactive protein, white blood cell count, and amniotic fluid white blood cell count in women with preterm premature rupture of membranes.Obstet Gynecol., 88 (6): 1034-40.

33- van de Laar R, van der Ham DP, Oei SG, Willekes C, Weiner CP, Mol BW (2009): Accuracy of C-reactive protein determination in predicting chorioamnionitis and neonatal infection in pregnant women with premature rupture of membranes: a systematic review. Eur J Obstet Gynecol Reprod Biol., 147 (2): 124-9.

34- Cobo T ,Stepan M, Musilova I, Hornychova $\mathbf{H}$, Jacobsson B, Kacerovsky M (2016): Maternal serum Creactive protein in women with preterm prelabor rupture of membranes. PLoS One, 11 (3): e0150217.

35- Afrasiabi N, Mohagheghi P, Kalani M, Mohades G, Farahani $\mathbf{Z}$ (2014): The effect of high risk pregnancy on duration of neonatal stay in neonatal intensive care unit. Iran J Pediatr., 24 (4): 423-8. 